\title{
Relation between glucagon-like peptide 1 (GLP-1), Glucose dependent insulinotropic peptide (GIP) and HOMA index in university students
}

\section{Relación del péptido similar al glucagón 1 (GLP-1) y péptido insulinotrópico dependiente de glucosa (GIP) con índice HOMA en estudiantes universitarios}

\author{
GONZÁLEZ-SANDOVAL, Claudia Elena†*, DÍAZ-BURKE, Yolanda, UVALLE-NAVARRO, \\ Rosario Lizette and MEDEROS-TORRES, Claudia Verónica
}

\begin{abstract}
Universidad de Guadalajara, Centro Universitario de Ciencias Exactas e Ingenierías, Depto Farmacobiología, Laboratorio de Bioquímica
\end{abstract}

ID $1^{\text {st }}$ Author: Claudia Elena, González-Sandoval / ORC ID: 0000-0001-8479-0828, CVU CONACYT ID: 44588

ID $1^{\text {st }}$ Co-Author: Yolanda, Díaz-Burke / ORC ID: 0000-0001-5142-1495, CVU CONACYT ID: 272319

ID $2^{\text {nd }}$ Co-Author: Rosario Lizette, Uvalle-Navarro / ORC ID: 0000-0002-3566-2579, CVU CONACYT ID: 660368

ID $3^{\text {rd }}$ Co-Author: Claudia Verónica, Mederos-Torres / ORC ID: 0000-0002-6259-8904, CVU CONACYT ID: 663067

DOI: $10.35429 /$ JSL.2021.25.8.25.30

Received July 30 2021; Accepted December 30, 2021

\begin{abstract}
Introduction. Diabetes mellitus is a disease which affects recently at least 415 million people around the world. Obesity is the main risk factor for the development of this disease. In the development of insulin resistance influences several factors such as carbohydrates metabolism and the secretion of GLP-1 and GIP. Objective. Correlate levels of GLP-1 and GIP with HOMA in students. Methods. A cross-sectional study was performed, we determine glucose levels using dry chemistry and GIP, GLP-1 and insulin levels were quantified by ELISA technique. A Pearson correlation between HOMA. Besides, we stratify in normal weight, overweight and obesity and we did the correlation in the three groups. Results. 78 students in total. GIP increased according to the BMI and show difference between the three groups $\mathrm{p}=0.01$. The GLP- 1 did not modify. HOMA index and GIP had a correlation of 0.36 with a significance $\mathrm{p}=0.002$. In the other hand, HOMA index vs GLP-1 $\mathrm{r}=0.52$ ( $p=0.001)$; normal weight $r=0.94(p=0.001)$, overweight $\mathrm{r}=0.75(\mathrm{p}=0.001)$, obesity $\mathrm{r}=0.045(\mathrm{p}=0.001)$ respectively. Conclusions. GIP and GLP-1 correlate with HOMA. The better correlation was found in GLP-1 which is higher in people with normal weight and decreases in obesity. The correlation between GIP and HOMA was low.
\end{abstract}

GLP-1, Insulin resistance, Obesity

\section{Resumen}

Introducción. La diabetes mellitus es una enfermedad que afecta a 415 millones de personas en el mundo, la obesidad el principal factor de riesgo para el desarrollo. En el desarrollo de la resistencia a la insulina influyen diversos factores, entre ellos una alteración en el metabolismo de carbohidratos y la secreción de GLP-1 y GIP. Objetivo. Correlacionar los niveles de GLP-1 y GIP con HOMA en estudiantes. Metodología. Estudio transversal. Se cuantifico glucosa por el método de química seca y GIP, GLP-1 e insulina se cuantificaron por ELISA. Se realizó la correlación de Pearson entre HOMA y los niveles de GLP-1 y GIP. Además, se realizaron las correlaciones entre normopeso, sobrepeso y obesidad. Resultados. 78 estudiantes. El nivel de GIP se incrementó de acuerdo con el IMC y hubo diferencia en los tres grupos con una $\mathrm{p}=0.01$. Los niveles de GLP-1 no se modificaron. El índice HOMA y GIP tuvo una correlación de $\mathrm{r}=0.36$ con una significancia de $\mathrm{p}=0.002$. Conclusiones. GIP y GLP-1 se correlaciona con HOMA. La mayor correlación se obtuvo con GIP-1 en normopeso y disminuye en obesidad. La correlación de GIP vs HOMA tuvo una correlación baja.

GLP-1, Resistencia a la insulina, Obesidad

Citation: GONZÁLEZ-SANDOVAL, Claudia Elena, DÍAZ-BURKE, Yolanda, UVALLE-NAVARRO, Rosario Lizette and MEDEROS-TORRES, Claudia Verónica. Relation between glucagon-like peptide 1 (GLP-1), Glucose dependent insulinotropic peptide (GIP) and HOMA index in university students. Journal Simulation and Laboratory. 2021, 8-25: 25-30

*Correspondence to Author (email: claudia.gsandoval@academicos.udg.mx)

$\dagger$ Researcher contributing as first Author. 


\section{Introduction}

According to the international diabetes federation, this disease currently affects at least 415 million people around the world. This number is estimated to rise even higher. The regions with the highest prevalences (above 9\%) are in Africa, South America and Central America. (Alva, 2018)

There is no single cause for the development of this pathology, but risk factors such as demographic characteristics and clinical factors that have been shown to contribute to the development of this disease influence. However, the main risk factor is obesity, which contributes to a state of insulin resistance. (Alva, 2018)

Insulin resistance (IR) is a metabolic disorder characterized by an attenuated biological response to the action of this hormone. It is defined as a state in which a greater amount of insulin is needed to produce a normal biological response to a glucose load, that is, compensatory hyperinsulinism develops. (Martínez-Basilia et al., 2011)

Obesity induces IR and involves a large amount of substances that predispose the individual to an inflammatory state and metabolic complications. Genetic and environmental factors influence the development of IR, such as a hypercaloric diet high in trans-fats, obesity, aging and sedentary lifestyle. (Martínez-Basilia et al., 2011)

The HOMA index (Homeostasis Model Assessment) was proposed by Mathews in 1985 . It is the most widely used method to diagnose IR in humans and it was deduced from a mathematical equation that relates the function of $\beta$-pancreatic cells and fasting glucose and insulin concentrations (Wallace et al, 2004)

\section{Carbohydrate metabolism}

For their metabolism, organisms depend on the oxidation of complex organic compounds for energy. Among them, carbohydrates, glucose being the primary source of energy for all cells in the body, including the brain, erythrocytes and cells (Murray et al., 2009).
After the ingestion of carbohydrates with the diet, the intestinal mucosa begins to secrete certain hormones to regulate their concentration. Among these, the glucagon-like peptide 1 (Glucagon-Like Peptide 1, GLP-1) and the glucose-dependent insulinotropic peptide (Glucose-dependent Insulinotropic Polypeptide, GIP), collectively referred to as incretins. Incretins play an important role in regulating the function of the islets of Langerhans and blood glucose levels (Deacon \& Ahren, 2011)

The mechanism of action of GLP-1 involves stimulation of insulin secretion by $\beta$ cells in the islets of Langerhans in the pancreas leading to inhibition of glucagon secretion by $\alpha$ cells. Elevated insulin secretion results in the synthesis of GLP-1. This hormone acts on receptors located in the central nervous system in order to suppress appetite and reduce the rate of absorption of food into the blood by reducing gastric emptying. GLP-1 levels depend on the composition of the food eaten and higher levels are observed after high calorie foods rich in fat. (Adamska et al, 2014)

GIP receptors are not only found on $\beta$ cells in the islets of Langerhans in the pancreas, but also in adipose tissue, the central nervous system, the heart, the adrenal cortex, and the vascular endothelium. Additionally, GIP stimulates D cells in the pancreatic islets to secrete somatostatin and glucagon. Resistance to GIP has been observed in diabetic patients, which could be caused by a defect at the level of its receptor (Adamska et al, 2014).

Previous studies in which diabetic and non-diabetic people were compared in relation to the incretin effect, found that in people with type 2 diabetes mellitus, the effect of GIP was reduced, especially in the last phase of the response of the insulin compared to people who used as a control (Knop et al, 2007). The relationship between incretin secretion and adequate insulin secretion could give us an overview of the insulin control that is being carried out in each person and help us identify a possible lack of control that could lead to insulin resistance and diabetes in the long term. Therefore, the objective of this work is to correlate GLP-1, GIP with the HOMA index in university students. 


\section{Methodology}

The inclusion criteria were: being active students of the University where it was carried out, age range of 18-25 years, with a previous fast of 1012 hours, all those with a previous diagnosis of diabetes were excluded. A total of 78 students were recruited who met these criteria.

This work complies with the regulations established in accordance with the general health law on research and is based on the principles of the Declaration of Helsinki.

Demographic data (age and sex) and then somatometric data were taken from each volunteer. Weight, expressed in kilograms (kg), was obtained with a clinical scale and height, in meters (m), with its scale. Once these parameters were obtained, the clinical history was drawn up by direct questioning and the pathological family history and lifestyle habits were obtained. Each one signed an informed consent.

After this, a blood sample was taken, the sample was allowed to clot and was centrifuged at 3,500 rpm. Once the sample was centrifuged, the serum was separated into two aliquots; the first, for the determination of glucose, which was immediately processed in the semi-automated fujifilm dri-chem nx500i dry chemistry apparatus, which uses the enzymatic technique, and the second aliquot was used for the quantification of GLP-1, GIP, and insulin by the ELISA Bio-Plex 200 System Assay Human Diabetes kit method. The readings were carried out on the Magpix Luminex equipment using its instructions (Bio-plex, 2014)

Independently, the HOMA index was calculated from the values obtained from glucose and insulin according to the Martínez Basila formula (Martínez-Basilia et al., 2011) for each student and once the data was complete, we proceeded to perform correlation and other analysis.

\section{Statistic analysis}

For the relationship of variables, Pearson correlations are used to calculate r. For the differences between normal weight, overweight and obesity, a one-way ANOVA was performed. To identify differences between genders, a student's t-test was performed after a normality test (Kolmogorov-Smirnov).
The data were processed in the statistical programs Excel 2013 and Statgraphics Centurión XVI. A confidence level of $95 \%$ was used, therefore, $\mathrm{p}$ less than 0.05 was considered statistically significant.

\section{Results}

Of a total of 78 students, 11 had a normal BMI, 15 were overweight and 52 were obese. Table 1 shows the descriptive data of the population.

\begin{tabular}{|c|c|c|c|c|}
\hline & $\begin{array}{c}\text { Normo- } \\
\text { weight } \\
n=11\end{array}$ & $\begin{array}{l}\text { Overweight } \\
n=15\end{array}$ & $\begin{array}{c}\text { Obesity } \mathrm{n}= \\
52\end{array}$ & $\mathbf{p}$ \\
\hline $\begin{array}{l}\text { Age } \\
\text { (years) }\end{array}$ & $21.7 \pm 1.7$ & $21.6 \pm 1.8$ & $21.5 \pm 1.9$ & 0.92 \\
\hline $\begin{array}{l}\text { BMI ( } \mathrm{kg} / \\
\mathrm{m} 2)\end{array}$ & $22.0 \pm 2.0$ & $27.9 \pm 1.5$ & $33.8 \pm 4.1$ & $0.00^{*}$ \\
\hline $\begin{array}{l}\text { Glucose } \\
(\mathrm{mg} / \mathrm{dL})\end{array}$ & $73.8 \pm 5.8$ & $74.2 \pm 7.3$ & $75.9 \pm 8.1$ & 0.59 \\
\hline $\begin{array}{l}\text { Insulin } \\
(\mathrm{pg} / \mathrm{mL})\end{array}$ & $170.6 \pm 74.2$ & $190.4 \pm 94.3$ & $254.1 \pm 120$ & $0.02 *$ \\
\hline GLP-1 & $121.3 \pm 30.0$ & $120.0 \pm 40.2$ & $126.6 \pm 30.3$ & 0.77 \\
\hline $\begin{array}{l}\text { GIP (pg / } \\
\text { mL) }\end{array}$ & $71.4 \pm 12.2$ & $63.1 \pm 17.1$ & $82.5 \pm 26.6$ & $0.01 *$ \\
\hline HOMA & $0.7 \pm 0.3$ & $0.8 \pm 0.4$ & $1.14 \pm 0.5$ & $0.01 *$ \\
\hline
\end{tabular}

BMI (Body Mass Index, GLP-1 (Glucagon-Like Peptide-1), GIP (Glucose-dependent Insulinotropic Polypeptide), HOMA (Homeostasis Model Assessment).

Table 1 Descriptive data

In this Table we can see the data for each group, normal weight (BMI 18.5-24.9), overweight (BMI 25-29.9) and obesity (BMI> 30). They are presented as means \pm standard deviation. An ANOVA was performed for each parameter and the result is shown in column $\mathrm{p}$, where the statistically significant are highlighted with * $(\mathrm{p}<0.05)$

It is observed that in age the three groups were very similar, the difference found in BMI was to be expected, since this was the way to stratify, glucose did not give a difference, while insulin did give a statistically significant difference, this could be due to the increased BMI that contributes to the establishment of insulin resistance. The levels of GLP-1 and GIP were very similar in the three groups, and the HOMA index also gave a statistically significant difference, without being a diagnosis of insulin resistance.

To know the degree of relationship between the HOMA index and the levels of the GIP and GLP-1 incretins, the Pearson correlation test was performed. 
The results are represented by (r), to know the degree of correlation of the variables and by (p) to know if there is a statistical significance between the correlations. The results obtained in Table 2 are shown below.

\begin{tabular}{|c|c|c|c|c|}
\hline & $\begin{array}{c}\text { general } \\
n=78\end{array}$ & $\begin{array}{c}\text { Normo- } \\
\text { weight } \\
n=11\end{array}$ & $\begin{array}{c}\text { Overweight } \\
\qquad \begin{array}{c}n=15\end{array}\end{array}$ & $\begin{array}{c}\text { Obesity } \\
\mathrm{n}=52\end{array}$ \\
\hline $\begin{array}{l}\text { GLP-1 } \\
\text { r } \\
\text { p value }\end{array}$ & $\begin{array}{r}0.54 \\
0.00 *\end{array}$ & $\begin{array}{r}0.94 \\
0.00 *\end{array}$ & $\begin{array}{r}0.75 \\
0.00 *\end{array}$ & $\begin{array}{r}0.45 \\
0.00 *\end{array}$ \\
\hline $\begin{array}{l}\text { GIP } \\
\mathrm{r} \\
\mathrm{p} \text { value }\end{array}$ & $\begin{array}{r}0.36 \\
0.00^{*}\end{array}$ & $\begin{array}{l}0.27 \\
0.42\end{array}$ & $\begin{array}{l}0.25 \\
0.35\end{array}$ & $\begin{array}{r}0.33 \\
0.02 *\end{array}$ \\
\hline
\end{tabular}

Table 2 Incretin correlations with the HOMA index

This Table shows the results of the Pearson correlations made between GLP-1 and GIP and the HOMA index, this in our general population, and stratified in groups of normal weight, overweight and obesity. The $r$ value represents the correlation coefficient and the $\mathrm{p}$ value the statistical significance. Those statistically significant correlations were marked with * (p $<0.05)$

In this Table we can see that the incretin that most correlates with the insulin resistance index was GLP-1, which decreased as the volunteers presented higher BMI, from which we could conclude that its incretin effect is diminished by the increased adiposity. While in GIP a significant correlation is not found if not up to the state of obesity.

\section{Discussion}

During the obesity process, insulin often disrupts the proper storage of glucose and suppresses hepatic glucose production, resulting in hyperglycemia, which is associated with a state described as insulin resistance. This insulin resistance promotes an increase in $\beta$ cell mass and increases insulin secretion to normalize glucose levels, resulting in hyperinsulinemia. In obese patients, insulin resistance eventually results in $\beta$ cell dysfunction, which leads to the inability to control blood glucose, and leads to type 2 diabetes mellitus (Roth et al, 2016)
Obesity has been associated with the development of important chronic-degenerative diseases such as: hypertension, metabolic syndrome, diabetes mellitus (DM), cardiovascular diseases (CVD), cancer, among others. (Williams et al, 2015) And it has been described to be associated with an increase in the severity of infectious diseases such as coronavirus, influenza, for influenza and rhinovirus.

In addition, in 2009 it was recognized as an independent risk factor in the pandemic caused by the variant of influenza A, H1N1. (Kwok et al, 2020) On the other hand, in the current COVID19 pandemic, various studies have shown that the risk of severe disease is increased in the presence of obesity, as well as the rate of hospitalization and a negative result. (Druncker D.J., 2021)

In our results we found HOMA index values of $1.14 \pm 0.53$ for obese, 0.8 and 0.7 for overweight and normal students respectively with a $\mathrm{p}=0.01$ which leads us to think that there is a disability of $\beta$ cells in obese subjects which leads to hyperinsulinemia to try to compensate for this dysfunction, finding elevated levels of insulin, normal glucose and presenting differences in the HOMA index between the three groups. (Table I). However, as the BMI of the students increases, there is an increasing trend in both insulin secretion and the HOMA index.

On the other hand, these results are similar to those reported by Hinnoucho (Hinnouho et al, 2013) where they report HOMA values of 1.1 in a population of metabolically healthy obese and 1.7 for non-metabolically healthy obese, the age range of the The population studied by this group was between 39 and 62 years, unlike our study where the age range was 18 to 24 years. This leads us to think that the population studied is probably metabolically healthy obese, given that a high value of insulin resistance is not observed, but it is likely that the metabolism of these young people will alter in the coming years, if they continue with the same life habits. On the other hand, GIP and GLP-1 are known as incretin hormones, since one of their functions is to increase insulin secretion after the ingestion of carbohydrates, some amino acids and lipids. GLP-1 also helps to delay gastric emptying, this increases the satiety signal, among other functions. (Palou et al, 2014) 
It is believed that some of the mechanisms involved in the development of insulin resistance are the decreased action of GIP and GLP-1, in people with obesity. (Knop et al, 2007) GLP-1 levels remained constant in the three groups, while in GIP we found an increase in the levels as the BMI increased with a $\mathrm{p}=0.01$, which could indicate that as there is a greater accumulation of adipose tissue, a greater secretion of incretins is required and this effect is only seen in GIP in our population (Adamska et al, 2014). In this work, GIP and GLP-1 levels were observed within the normal values for a healthy population reported in the ELISA KIT insert (Wang et al, 2010), this means that the incretin levels are still normal despite the obesity.

One of the functions of incretins is their insulinotropic function, which is why it was decided to correlate these proteins with the HOMA index, since this relationship could be of interest because it speaks of a control over glucose metabolism that is modified in obesity (Adamska et al, 2014)

We found a Pearson correlation of GIP vs HOMA index $r=0.36, p=0.00$ and GLP-1 vs HOMA index $r=0.54, p=0.00$ in the general population. When we analyze the correlations according to their BMI, we find a similar behavior in GIP between the three groups, this due to the fact that there is an increase in GIP and HOMA in the groups simultaneously, while in GLP-1 it is observed that the correlation is decreasing since the GLP-1 values are maintained, but those of HOMA increase. These findings could indicate that, in young people, the incretin effect is carried out mainly through GIP and could give us a new therapeutic target for people who later develop diabetes. Contrary to what is normally used in GLP-1 clinical practice. (Tran et al, 2017)

The values obtained from the correlations in the case of GLP-1 decreased as the BMI increased. In the literature, we are told that incretin activity is decreased in the state of obesity. Here we can say that this incretin did not exercise its role properly and I was replaced by GIP, so we can say that despite being obese, these subjects can still exercise adequate metabolic control in other ways, perhaps due to the short time of establishment of the obesity due to their short age range (Aulinger et al, 2015).

\section{Conclusions}

GIP and GLP-1 are positively correlated in a moderate to strong way with the HOMA index, the correlation being higher with GIP-1, which is strong in people with normal weight and moderate in people with obesity. The GIP vs HOMA correlation was maintained despite obesity.

Obesity is known to be the result of chronic deterioration, of many years of evolution, and although the population we study is obese, this is not yet reflected in the decrease in incretin levels. However, this could be modified if the same lifestyle is continued and the obesity process continues to perpetuate.

This study sets a precedent for the levels of GIP and GLP-1 in this population of young people. In addition, it encourages the continuation of this line of research, even determining the levels of other proteins involved in carbohydrate metabolism to see interactions between them. Which could give us a more complete picture.

\section{References}

Adamska E., Ostrowska L., Gèórska M., Krętowski A., The role of gastrointestinal hormones in pathogenesis of obesity and type 2 diabetes. Gastroenterology review. 2014 9(2):69-76. DOI: $10.5114 /$ pg.2014.42498.

Alva ML. (2018). A Review of the Impacts of Different Approaches for Diabetes Prevention and a Framework for Making Investment Decisions. Int J Environ Res Public Health.15 (3): 522. DOI: 10.3390/ijerph15030522

Aulinger B.A., Vahl T.P., Wilson Pérez H.E., Prigeon R.L, D'Alessio D.A. (2015) $\beta$-cell sensitivity to GLP-1 in healthy humans is variable and proportional to insulin sensitivity. $\mathrm{J}$ Clin Endocrinol Metab. $1-8$ DOI: 10.1210/jc.2014-4009

Bio-Plex Pro. (2014) Diabetes Assay, instruction manual.

Deacon C.F., Ahrén B. (2011), Physioly of Incretins in Health and Disease. Rev Diabet Stud. 8(3): 293-306. DOI: 10.1900/RDS.2011.8.293. 
Drucker D. J. (2021). Diabetes, obesity, metabolism, and SARS-CoV-2 infection: the end of the beginning. Cell metabolism, 33(3), 479-498.

https://doi.org/10.1016/j.cmet.2021.01.016

Hinnouho G.M., Czernichow S., Dugravot A., Batty G.D., Kivimaki M., Singh Manoux A. (2013) Metabolically Healthy Obesity and Risk of Mortality. Does the definition of metabolic health matter? Diabetes Care. (36) 2294-2300. DOI: $10.2337 / \mathrm{dc} 12-1654$

Knop F.K., Vilsboll T., Hojberg P., Larsen S., Madsbad S., Volund A., Holst J., Krarup T. (2007) Reduced Incretine Effect in Type 2 Diabetes. Diabetes journal. 56. 1951-1959. DOI: 10.2337/db07-0100

Kwok, S., Adam, S., Ho, J. H., Iqbal, Z., Turkington, P., Razvi, S., Le Roux, C. W., Soran, H., \& Syed, A. A. (2020). Obesity: A critical risk factor in the COVID-19 pandemic. Clinical obesity, 10(6), e12403. https://doi.org/10.1111/cob.12403

Martínez Basila A, Maldonado Hernández J, López Alarcón M. (2011) Métodos diagnósticos de la resistencia a la insulina en la población pediátrica. Bol Med Hosp Infant Mex. 68(5) 397-404.

Murray R., Bender D., Botham K., Rodwell V., Weil P. A. Harper. (2009) Bioquímica ilustrada. 28a Edición. México D.F., Editorial McGrawHill Interamericana

Palou A., Bonet ML., Picó C., Rodríguez AM. (2014) Nutrigenómica y obesidad. Rev. med. univ. Navarra. (48): 36-48

Roth Flach R.J., Danai L.V., DiStefano M.T., Kelly M., García Menendez L., Jurezyk A., Sharma R.B., Young Jung D., Hun Kim J., Kim J.K., Bortell R., Alonso L.C., Czech M.P. (2016) Protein kinase Mitogen Activated Protein Kinase 4 (MAP4K4) Promotes Obesity-Induced Hyperinsulinemia. J Biol Chem. 291(31): 16221-16230. DOI:10.1074/jbc.M116.718932.

Tran KL, Park YI, Pandya S, Muliyil NJ, Jensen BD, Huynh K, Nguyen QT. (2017) Overview of Glucagon-Like Peptide-1 Receptor Agonists for the Treatment o Patients with Type 2 Diabetes. Am Health Drug Benefits. 10(4):178-188.
Wallace T.M., Levy J.C., Matthews D.R. (2004) Use and abuse of HOMA modeling. Diabetes Care. 27:87-95

Wang Q.S., Zhou H., Yeung D., Ma L., Geng W. (2010) Development and Validation of Multiplex Assays for Human Diabetes Biomarkers. Bio-Plex suspension array system. 2010. 1-4

Williams, E. P., Mesidor, M., Winters, K., Dubbert, P. M., \& Wyatt, S. B. (2015). Overweight and obesity: prevalence, consequences, and causes of a growing public health problem. Current obesity reports, 4(3), 363-370. 